\title{
Valorisation of Auriferous Indices: Case of the Siribaya Deposit, Western Mali
}

\author{
Fodé Tounkara ${ }^{1,2 *}$, Jianguo Chen², Mory Sidibe1, Oumar Soumare ${ }^{3}$, Adama Youssouf Koné ${ }^{4}$ \\ ${ }^{1}$ Université de Ségou, Ségou, Mali \\ ${ }^{2}$ State Key Laboratory of Geological Processes and Mineral Resources, China University of Geosciences, Wuhan, China \\ ${ }^{3}$ Ecole Nationale d’Ingènieurs Abderhamane Baba Touré, Bamako, Mali \\ ${ }^{4}$ Laboratoire de Cartographie, Département de Géologie, Faculté des Sciences et Techniques (FST), Université des Sciences, des \\ Techniques et des Technologiques de Bamako (USTTB), Bamako, Mali \\ Email: ^fode1986@yahoo.fr
}

How to cite this paper: Tounkara, F., Chen, J.G., Sidibe, M., Soumare, O. and Koné, A.Y. (2021) Valorisation of Auriferous Indices: Case of the Siribaya Deposit, Western Mali. Open Journal of Geology, 11, 457-470.

https://doi.org/10.4236/ojg.2021.1110024

Received: February 23, 2021

Accepted: October 19, 2021

Published: October 22, 2021

Copyright $\odot 2021$ by author(s) and Scientific Research Publishing Inc. This work is licensed under the Creative Commons Attribution International License (CC BY 4.0).

http://creativecommons.org/licenses/by/4.0/

(c) (i) Open Access

\begin{abstract}
The purpose of this paper is to understand the valorization of gold showings in the Seribaya deposit, western Mali. Samples taken from Air Core (AC) boreholes were subjected respectively to the magnetic susceptibility test and the $\mathrm{X}$-ray fluorescence analysis. These results lead to the development of a simple methodology, based on signatures/indicators geochemical to identify lithology or to locate mineralization. We note that, compared to other chemical elements, Arsenic remains the most correlated with gold in the study area. Since this correlation remains weak $(r=0.16)$, it shows that Arsenic does not always accompany gold. There would be a generation of Arsenic related to mineralization, and other generations that would not be. The observation of the strip logs led to the identification of the lithologies (focusing on the immobile elements, Ti, V, Cr, Y, Zr) and the establishment of the alteration profile. Highly altered levels (Saprolite \pm Saprock) are characterized by the disappearance of most mobile elements. A medium to strong correlation between gold mineralization and magnetic susceptibility measurements has been observed, in some places, and at depths. These mineralized intervals typically consist of quartz veins, suggesting that they have structural control over the mineralization. Gold mineralization is believed to be related to quartz veins. In addition, gold would be in paragenesis with a generation of Arsenic hosted in coarse sediments.
\end{abstract}

\section{Keywords}

Valorization, Gold Index, Strip Logs, Magnetic Susceptibility 


\section{Introduction}

In Mali, gold export has substantially increased since the 1990s [1]. The Siribaya deposit is located in the eastern part of Kedougou Kéniéba Inlier (KKI). From the geological point of view, the study area is located in West Africa Craton (Figure 1). This sector contains several gold deposits (e.g., Wiliwili, Hamdallaye, Dandôko) that are located around the Senegalese-Malian Shear-Zone (SMSZ) within the Kofi group. The SMSZ and its secondary structures are recognized as controlling gold mineralization in the KKI. The intensity of gold Artisanal Mining Sites (AMS) emphasizes that the study area is a highly promising area in gold. Prospective studies are still ongoing in these areas in order to find resources that can be exploited.

The purpose of this paper is to valorize the gold showings while identifying the possibilities and methodologies that are favorable. West Africa suffers from artisanal and small-scale mining formalization problems as other mineral-rich countries in the region [2]. The purpose of this paper is to understand the valorization of gold showings in the Seribaya deposit, western Mali.

\section{Geological Setting}

The West African Craton (WAC) is composed of Archean age formations at
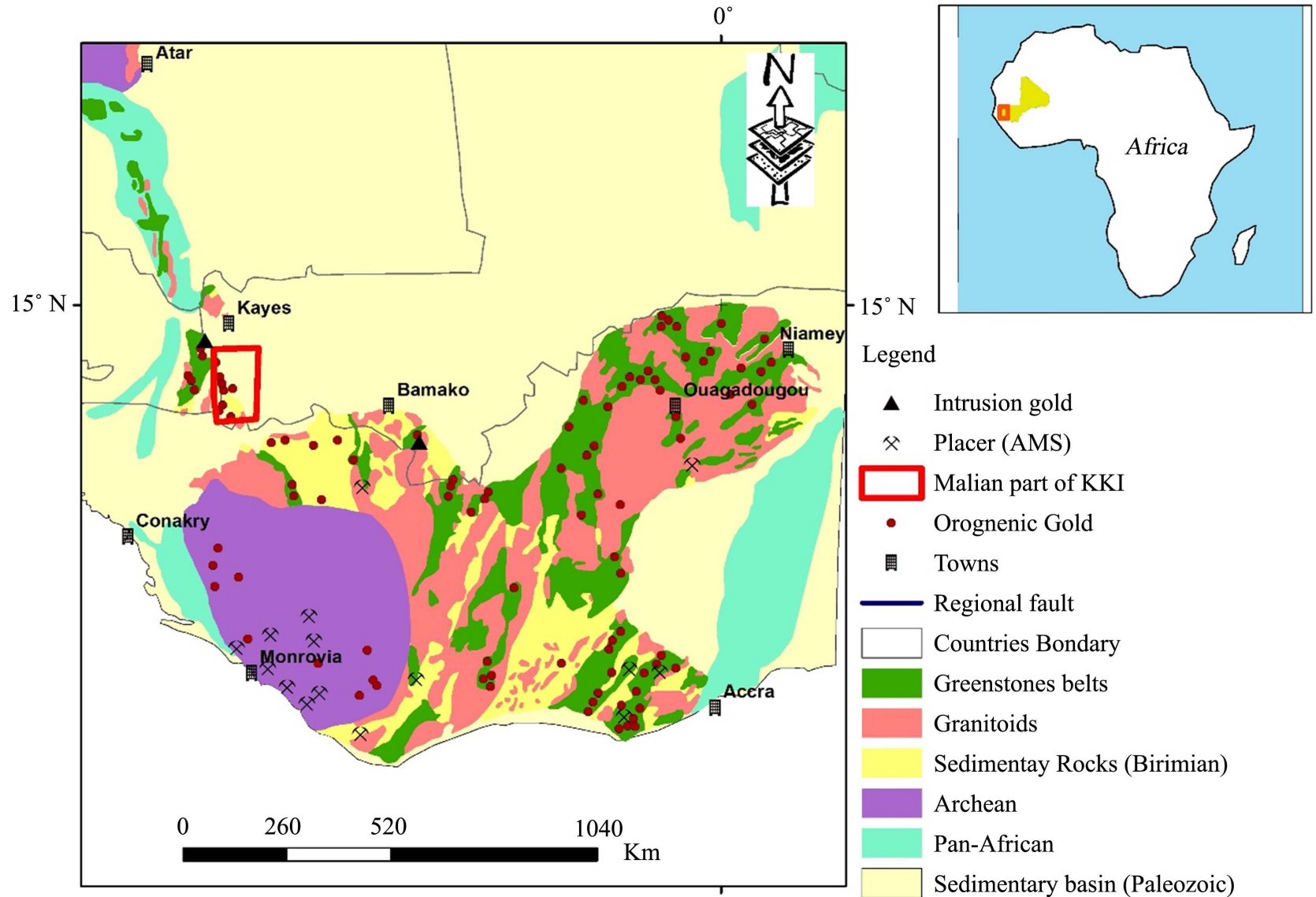

Figure 1. Geological map of West African Craton (after [15], simplified by [16]). 
Proterozoic paleo and has undergone numerous tectonic movements before being canonized in a single block. The WAC is bounded on the north and south by the Réguibat and Léo Man shields (Figure 1), and halfway between these two shields are the Kédougou-Kéniéba (Senegal and Mali) and Kayes (Mali) Inliers [3]. These geological zones have been subdivided into domains including: the sedimentary domain, the pan-African folded belts, and the Hercynian belts (Figure 1).

This WAC has an opening zone known as the Kedougou-Kenieba Inlier (KKI), which is located on the Senegal-Malian border (Figure 1). According to the available geological information [4] [5] [6], there is limited research on gold resource in Mali. Then further study with the realization of the thin blade or fluid inclusion could answer this question [7] [8]. The interaction of hydrothermal fluids with metamorphosed carbonaceous matter (CM) could be one of the causes of the reduction of hydrothermal fluids and the formation of the respective mineralization [9]. However, all primary gold deposits in West Africa can be classified as orogenic type gold deposits [10]. The WAC is formerly subdivided into two (2) sectors, which are: The Mako sector, the Dialé-Daléma sector [11]. This district is located in the KKI, which is of deformed Birimian rocks (Paleoproterozoic, ca. 2200 - 2050 Ma. The KKI outcrop is in eastern Senegal and western Mali [12]. But in the Loulo-Gounkoto complex in the Kédougou-Kéniéba Inlier hosts three multi-million ounce orogenic gold deposits, situated along the Senegal-Mali Shear Zone [13]. In terms of deformation, sediments in the area show a weak cleavage on shale and greywackes. This cleavage is more penetrating in the graphite pelites with some levels of shale [14] [15].

However, Alamoutala gold deposit is part of the Yatela gold district [16] [17] [18] [19]. From a geological point of view, the study area is located in the Birimian formations of the Kedougou-Kéniéba Inlier. The lithologies observed at Kofia II, Kofia-South and Babara show sediments consisting of shales, greywackes and pelites, sands, pelite graphites oriented around $\mathrm{N} 200^{\circ}$ with a mean dip around $60^{\circ} \mathrm{W}$. The identified magmatic rocks are gabbros, diorites, granodiorites, and granites [20] [21] [22].

\section{Research Methodology}

This paper discusses the methodologies adopted for the valorization of gold showings.

The methodology applied for this gold index valuation study focused on the measurement of magnetic susceptibility through the SM30 instrument, and on the geochemical analysis of the X-ray elements, on the other hand. Their fluorescence on the samples: Olympus X-5000.

In this paper, the first work begins with the treatment that is based on the AC drill samples, the lithological description, the magnetic susceptibility measurements. The next step is the X-ray analysis, and the establishment of the trip logs under the Geosoft software. Finally, the use of binary diagrams visualizes the 
spatial distribution of each sample according to its content of Ti, $\mathrm{Zr}, \mathrm{Fe}, \mathrm{Mn}$.

\subsection{Measurements of Magnetic Susceptibility}

Magnetic susceptibility is a physical parameter that makes it possible to measure the reaction of a body subjected to a magnetic field.

It is during the composite sampling that approximately $200 \mathrm{~g}$ of each metric sample is taken and placed in a plastic bag and will be used to carry out a magnetic susceptibility test.

An observation of the strip logs was realized with the data resulting from the magnetic susceptibility. It shows an increase in magnetic susceptibility in lateritic cuirass zones (Figure 2 \& Figure 3).

We notice a peak of magnetic susceptibility in sandstone and corresponding to a quartz vein zone. When excluding any erroneous value, this peak could correspond to the presence of magnetic sulphide such as pyrrhotite or oxides such as magnetite. This interval corresponds to a mineralized zone, which suggests the existence of a spatial relationship between gold and pyrrhotite or magnetite. This hypothesis remains partial until we have more data to corroborate this statement (Figure 2).

We also notice a medium magnetic susceptibility mainly in the lithologies described as argillites. This magnetism may be due to the graphite alteration in this unit (Figure 3).

SRA17-399 Lithology Alteration profile $\quad \mathrm{Au} \quad \%$ quartz fragments Magnetic susceptibility

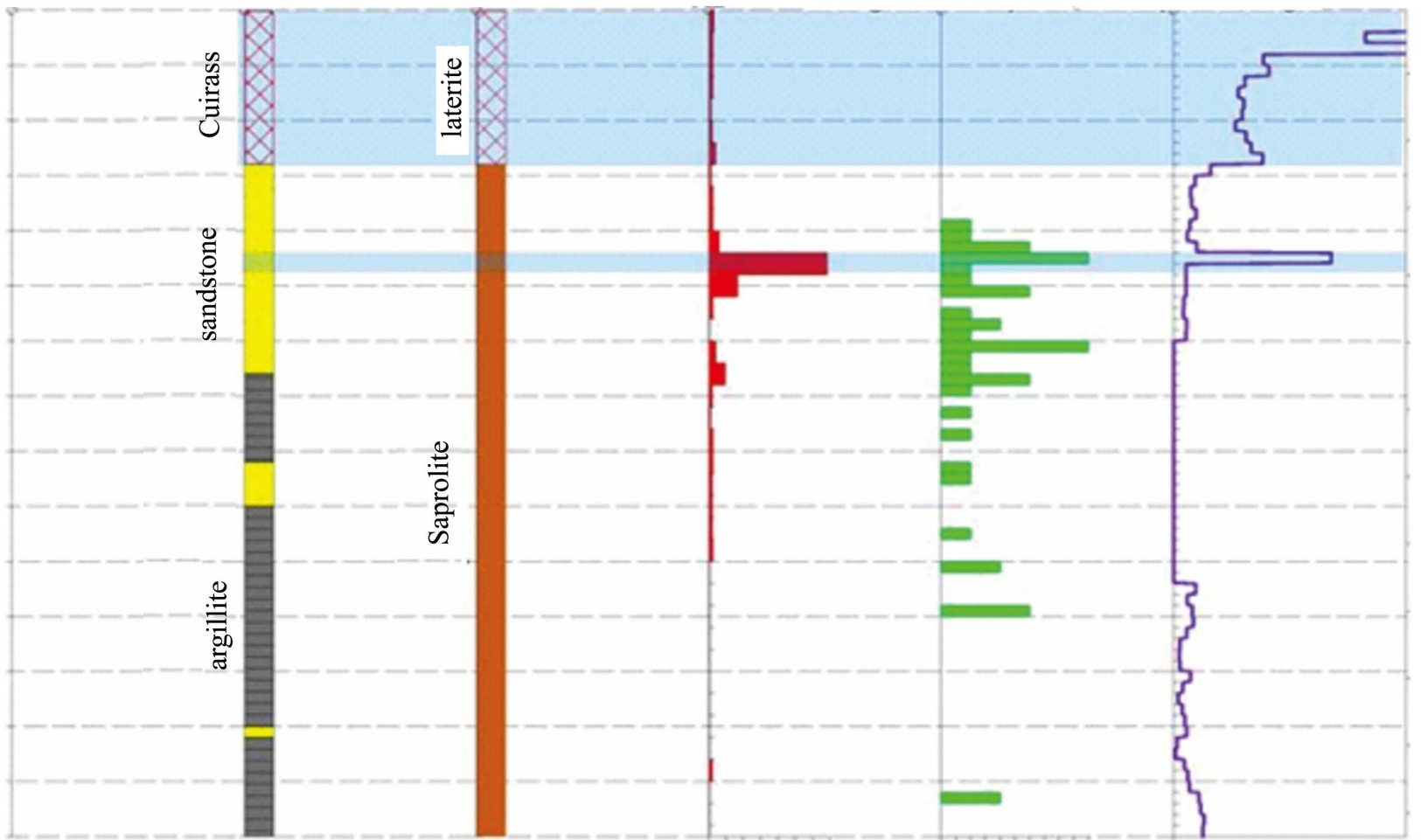

Figure 2. Strip log showing the evolution of magnetic susceptibity in the different lithologies of drilling SRA17-399. 


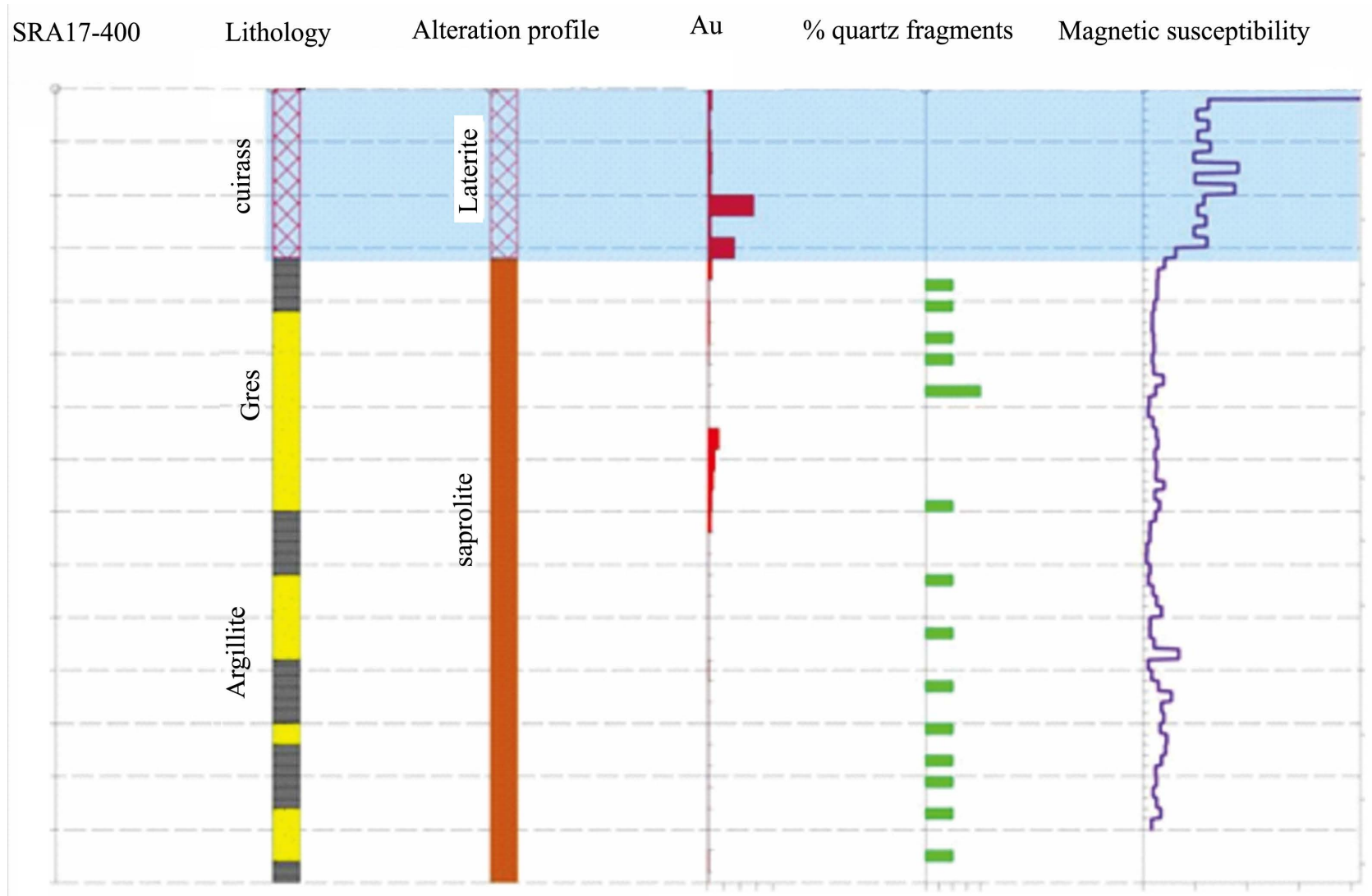

Figure 3. Strip log showing the evolution of the magnetic susceptibility in the different lithologies of drilling SRA17-400.

In view of the different observations, we could deduce that the gold mineralization has a structural control with respect to the spatial relationship between the zones of quartz veins and the presence of gold. Even if this relationship is not totally continuous over all the drillings, this could be justified by admitting that a certain category of the vein (that is to say of a given mineralogical composition) seems to confirm this hypothesis. In addition, some mineralized levels where quartz fragments have been observed have medium magnetic susceptibility to elevation, which probably corresponds to the presence of oxidized sulphide such as pyrrhotite or oxides such as magnetite. Due to the degree of oxidation, none of its elements could be observed on rock flakes.

\subsection{XRF Analyzes}

XRF (X-Ray Florescence) analysis is an analytical method that detects the chemical elements of a sample as it passes through the X-ray. The machine used by IEM is the Olympus X-5000. It is a table XRF giving semi-quantitative results. This tool is suitable for analyzing RC/DD samples.

The purpose is to evaluate the main litho-geochemical characteristics, while checking the type of lithology defined during the drilling description.

In Table 1 we have the correlation between gold and chemical elements from XRF analyzes. In Table 2 we have the results of XRF analyzes of two (02) holes 
Table 1. Degree of correlation between gold and chemical elements from XRF analyzes.

\begin{tabular}{|c|c|c|c|c|c|c|c|c|c|c|c|c|c|c|c|}
\hline & As & $\mathrm{Au}$ & $\mathrm{Ba}$ & $\mathrm{Ca}$ & $\mathrm{Cl}$ & Co & $\mathrm{Cr}$ & $\mathrm{Cu}$ & $\mathrm{Fe}$ & K & $\mathrm{Sr}$ & $\mathrm{Ti}$ & $\mathrm{V}$ & $\mathrm{Y}$ & $\mathrm{Zr}$ \\
\hline As & 1 & & & & & & & & & & & & & & \\
\hline $\mathrm{Au}$ & -0.16 & 1 & & & & & & & & & & & & & \\
\hline $\mathrm{Ba}$ & -0.17 & 0.01 & 1 & & & & & & & & & & & & \\
\hline $\mathrm{Ca}$ & 0.03 & -0.03 & 0.06 & 1 & & & & & & & & & & & \\
\hline $\mathrm{Cl}$ & 0.55 & 0.08 & -0.42 & -0.20 & 1 & & & & & & & & & & \\
\hline Co & 0.43 & 0.01 & -0.41 & -0.20 & 0.98 & 1 & & & & & & & & & \\
\hline $\mathrm{Cr}$ & 0.46 & 0.07 & -0.32 & 0.08 & 0.79 & 0.50 & 1 & & & & & & & & \\
\hline $\mathrm{Cu}$ & 0.30 & 0.04 & -0.12 & -0.11 & 0.39 & 0.19 & 0.36 & 1 & & & & & & & \\
\hline $\mathrm{Fe}$ & 0.51 & 0.05 & -0.35 & -0.13 & 0.98 & 0.87 & 0.76 & 0.35 & 1 & & & & & & \\
\hline $\mathrm{K}$ & 0.13 & -0.01 & 0.16 & 0.23 & -0.34 & 0.02 & 0.11 & 0.19 & 0.11 & 1 & & & & & \\
\hline $\mathrm{Sr}$ & -0.03 & -0.04 & 0.45 & 0.34 & -0.41 & -0.29 & -0.21 & -0.13 & -0.25 & -0.03 & 1 & & & & \\
\hline $\mathrm{Ti}$ & 0.35 & 0.03 & 0.01 & 0.20 & 0.69 & 0.24 & 0.62 & 0.36 & 0.50 & 0.67 & -0.10 & 1 & & & \\
\hline $\mathrm{V}$ & 0.46 & 0.05 & -0.11 & 0.09 & 0.90 & 0.45 & 0.74 & 0.48 & 0.73 & 0.56 & -0.14 & 0.89 & 1 & & \\
\hline $\mathrm{Y}$ & 0.08 & -0.01 & 0.18 & 0.09 & -0.17 & -0.03 & 0.24 & 0.25 & 0.12 & 0.54 & -0.12 & 0.70 & 0.58 & 1 & \\
\hline $\mathrm{Zr}$ & 0.04 & -0.02 & -0.2 & -0.26 & 0.25 & 0.36 & 0.11 & -0.08 & -0.34 & 0.15 & -0.34 & 0.40 & 0.26 & 0.38 & 1 \\
\hline
\end{tabular}

Table 2. Results of XRF analyzes of two (02) boreholes marked by the absence of data in yellow bottom and significant decrease in light green bottom observed for the same chemical element.

\begin{tabular}{|c|c|c|c|c|c|c|c|c|c|c|c|c|c|c|c|c|c|c|c|c|}
\hline Hole_ID & Code litho & As & $\mathrm{Ba}$ & $\mathrm{Ca}$ & Co & $\mathrm{Cr}$ & $\mathrm{Fe}$ & $\mathrm{Hf}$ & K & $\mathrm{Mn}$ & Mo & $\mathrm{Nb}$ & $\mathrm{Pb}$ & $\operatorname{Pr}$ & $\mathrm{Rb}$ & $\mathrm{Sr}$ & $\mathrm{Ta}$ & Th & $\mathrm{Ti}$ & $\mathrm{V}$ \\
\hline SRA14-175 & Granite & 28 & 408 & 1497 & 17.6 & 305 & 86,457 & 2.8 & 6778 & 90 & 15 & & 9 & & 25.5 & 117 & 69 & 6.4 & 1618 & 108 \\
\hline SRA14-175 & Granite & & 559 & 1277 & 3.2 & 28 & 12,729 & 4.4 & 9046 & 70 & & & & & 57.1 & 262 & 48 & 9.3 & 640 & 44.4 \\
\hline SRA14-175 & Granite & & 675 & 2276 & 2.3 & 21 & 10,213 & 3.1 & 8596 & 91 & & & & & 37.9 & 475 & 48 & 6.8 & 565 & 40.8 \\
\hline SRA14-175 & Granite & 11 & 692 & 4340 & 1.8 & 15.7 & 7546 & 3.6 & 7375 & 105 & & & 6.4 & & 38.9 & 595 & 53 & 13 & 492 & 37.2 \\
\hline SRA14-175 & Granite & & 725 & 4025 & 1.9 & 13.6 & 8218 & 3.1 & 7728 & 136 & & & & & 41.2 & 654 & 55 & 18 & 520 & 41.6 \\
\hline SRA14-175 & Granite & & 729 & 4869 & 2.2 & 12.5 & 8339 & 3.6 & 8287 & 130 & & & & & 42.2 & 590 & 56 & 17 & 564 & 43.2 \\
\hline SRA14-175 & Granite & & 665 & 3485 & 2.4 & 9.5 & 9201 & 3.1 & 7403 & 136 & & & 7 & & 44.2 & 529 & 48 & 10 & 540 & 39.8 \\
\hline SRA14-175 & Granite & & 739 & 4379 & 1.9 & 11.7 & 8553 & 3.6 & 8331 & 156 & & & & & 34.7 & 710 & 44 & & 511 & 42.8 \\
\hline SRA14-175 & Granite & & 692 & 5437 & 2.2 & 10.2 & 8190 & 3.9 & 7703 & 152 & & & & & 37 & 674 & 39 & 14 & 528 & 44.1 \\
\hline SRA14-175 & Granite & & 741 & 4153 & 2.4 & 11.7 & 8318 & 4 & 8331 & 158 & & & 6.8 & & 39.7 & 721 & 41 & 14 & 531 & 40.3 \\
\hline SRA14-175 & Granite & & 723 & 4153 & 1.9 & 10.3 & 8643 & 5.6 & 7703 & 134 & & & & & 48.2 & 599 & 60 & 14 & 497 & 40.7 \\
\hline SRA14-175 & Granite & & 764 & 5442 & 2.3 & 11 & 8318 & 5.4 & 7294 & 107 & & & 6.8 & & 38.6 & 662 & 51 & 13 & 534 & 47.7 \\
\hline SRA14-175 & Granite & & 746 & 5920 & 1.9 & 7 & 8252 & 4.2 & 7807 & 119 & & & 7.6 & & 31.8 & 733 & 46 & 16 & 542 & 41.1 \\
\hline SRA14-175 & Granite & & 733 & 7303 & 2.3 & 10.3 & 10,182 & 3.8 & 9336 & 113 & & & & & 32.5 & 758 & 52 & 17 & 486 & 39.6 \\
\hline SRA14-175 & Granite & 13 & 715 & 8123 & 1.9 & 13.1 & 8893 & 5.5 & 7501 & 129 & 10 & & & & 31.4 & 709 & 55 & 21 & 483 & 38.6 \\
\hline SRA14-175 & Granite & & 646 & 7115 & 2.1 & 16.5 & 8613 & 4.1 & 6508 & 146 & & & & & 39.1 & 670 & 46 & 15 & 457 & 37.4 \\
\hline SRA14-175 & Granite & & 799 & 7327 & 1.5 & 18 & 9032 & 2.8 & 6465 & 135 & & & & & 31.1 & 716 & 31 & 15 & 532 & 38.6 \\
\hline SRA14-175 & Granite & & 621 & 8233 & 1.8 & 17 & 8198 & 3.9 & 7603 & 132 & & & & & 33.2 & 743 & 53 & 16 & 452 & 41.5 \\
\hline
\end{tabular}




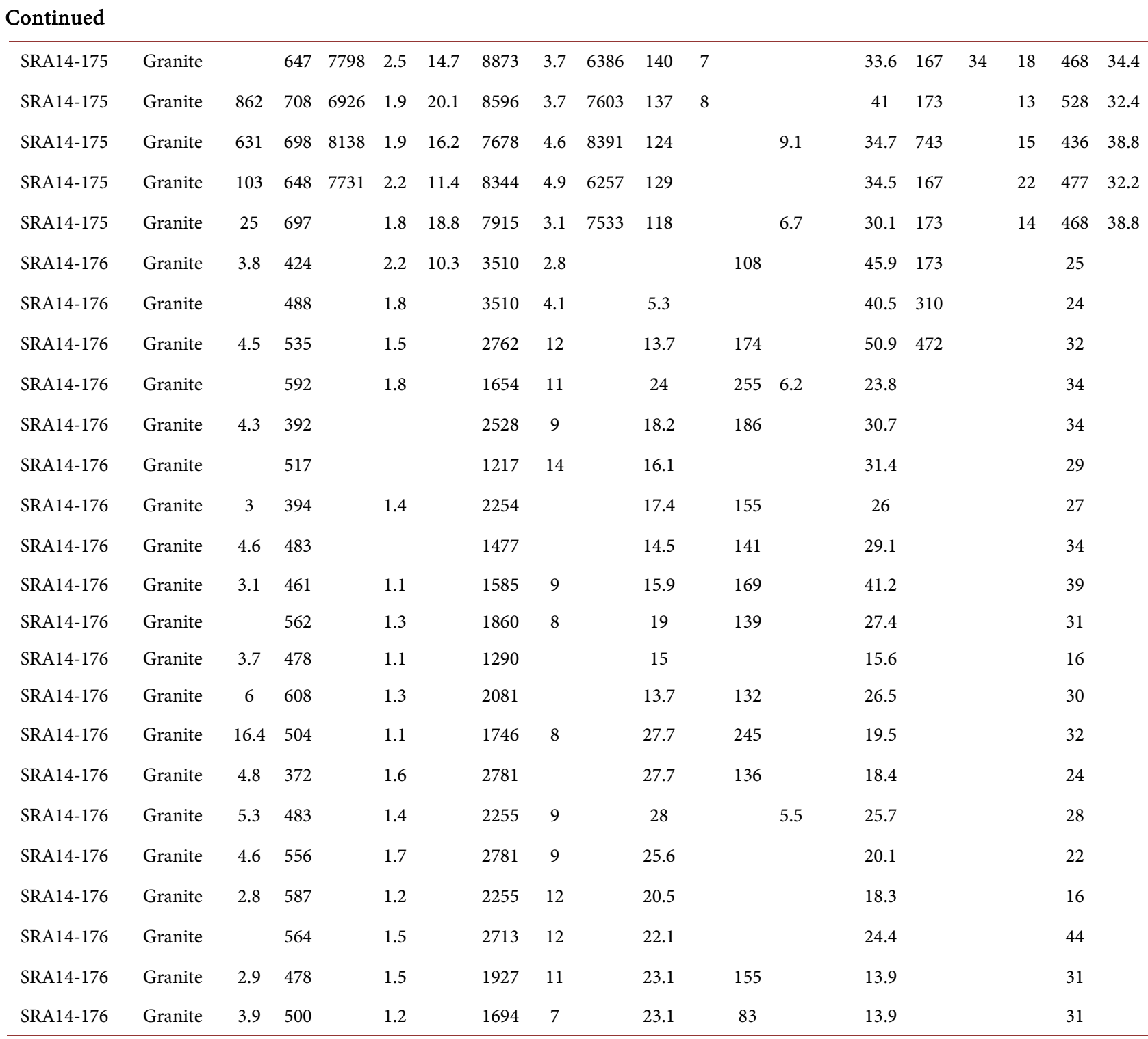

marked by the absence of yellow background data and a significant decrease in light green background observed for the same chemical element.

Correlation coefficients provide a synthetic measure of the intensity of the relationship between two characters (populations) and its meaning when this relationship is monotonic.

Let $(r)$ be the correlation coefficient between two variables, it varies between -1 and +1 . The sign of $r$ thus indicates the direction of the relationship while its absolute value represents the intensity of the relation.

That is, the ability to predict the values of $Y$ versus $X$.

The correlation matrix produced under Geosoft shows that only arsenic (As) is the chemical element with a very low correlation coefficient ( $r$ ) with Au. It is $0.16(r=0.16)$ and has a population sufficient to mark an exploitable correlation with Au.

Other elements with sufficient population also show strong to medium corre- 
lations between them, these are:

$\mathrm{Ni}$ is very strongly correlated with $\mathrm{Rb}(\mathrm{r}=0.98)$ and $\mathrm{Th}(\mathrm{r}=0.87)$.

$\mathrm{Fe}$ is very strongly correlated with $\mathrm{Co}(\mathrm{r}=0.86)$, and strongly with $\mathrm{Cr}(\mathrm{r}=$ 0.75).

Ti is moderately correlated with $\mathrm{Cr}(\mathrm{r}=0.65), \mathrm{K}(\mathrm{r}=0.70)$.

$\mathrm{Zr}$ is moderately correlated with $\mathrm{Ni}(\mathrm{r}=0.71)$.

Binary Diagram to Discriminate Lithology

The 2-variable scattering diagrams used to discriminate the lithology in function of facies are as follows:

- Diagram of Titanium (Ti) versus Zirconium (Zr);

- Diagram of Iron (Fe) versus Manganese (Mn).

The aim was to make a diagram for distinguishing intrusive rocks from sedimentary rocks, Ti/Zr diagram (Figure 4), and a second diagram was made for the purpose of differentiating fine sediments from very fine, Fe diagram/Mn, (Figure 5).

An observation of the Ti/Zr diagram shows a fairly consistent dispersion of the different lithologies. As for the lithology described as granite, it is represented by two very distinct point clouds (granite 1 and 2), which suggests the existence of two distinctly different lithologies.

On the Fe/Mn diagram (Figure 5) we notice a superposition of lithologies defined as greywacke or shale, it can be explained that these two lithologies are probably from the same source (porthole) or that it is acts of the same lithology or a variation of granulometry having been described otherwise. The Fe/Mn diagram confirms the superposition of greywackes and shales. The lithology defined as granite also forms a cloud of quite distinct points, less enriched in Fe. As a reminder, the values below 25,000 ppm for the Fe have been discarded which could justify the only point cloud obtained. The lateritic cuirass is distinctly distinct, with high Fe content.

In fact, the use of binary diagrams made it possible to visualize the distribution space of each sample according to its content of Ti, $\mathrm{Zr}, \mathrm{Fe}, \mathrm{Mn}$.

\section{Results and Discussion}

In this paper, the result of the study gave the characterization of the lithologies. These proven lithologies can be classified and give the markers of gold mineralization.

\subsection{The Intrusive Rocks}

The intrusive rocks are essentially the granites whose geochemical characteristics are underlined by peaks of $\mathrm{Ba}, \mathrm{Sr}, \mathrm{K}$ against a $\mathrm{Zr}$ and $\mathrm{Ti}$ depletion and to see a total absence of $\mathrm{Cr}, \mathrm{Co}, \mathrm{Fe}$.

Strip logs show that at certain levels, specifically in saprolitic zones, decreases in the content of elements such as $\mathrm{Ba}, \mathrm{K}, \mathrm{Sr}$. This can be explained by the degree of mobility of these chemical elements (Figure 6). 


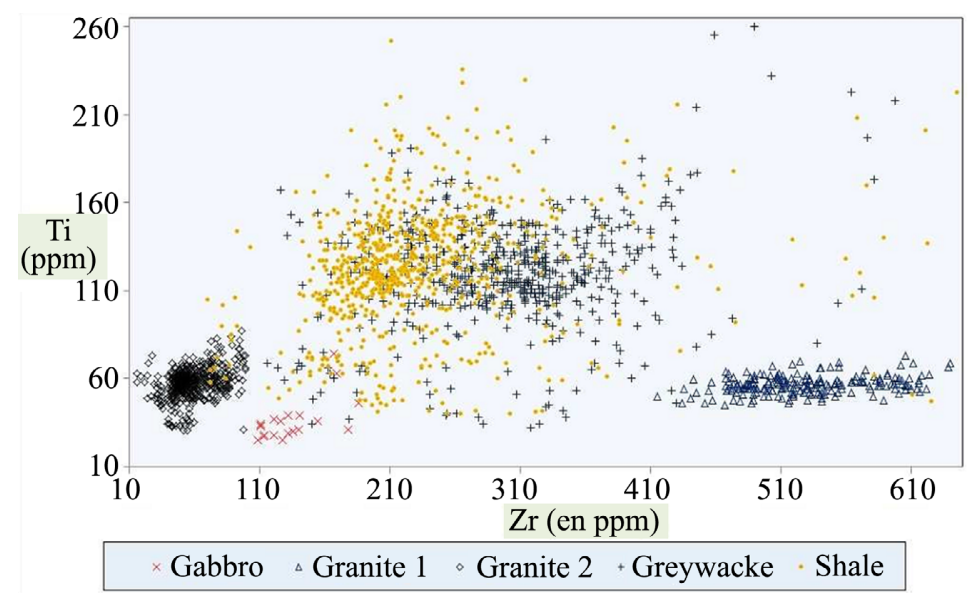

Figure 4. Distribution of the different lithologies according to the contents of Ti and $\mathrm{Zr}$.

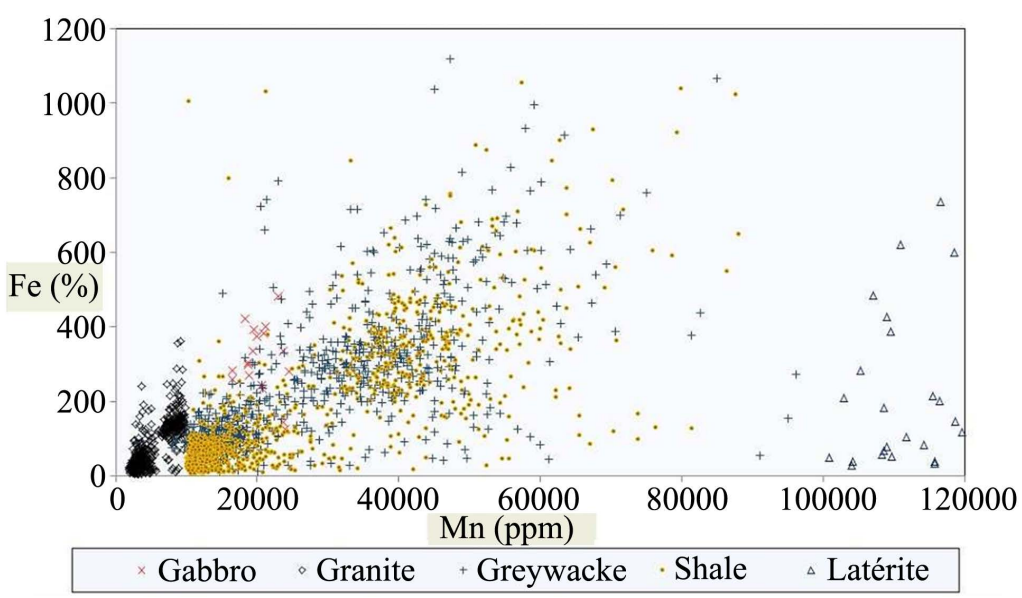

Figure 5. Distribution of the different lithologies according to their Fe and Mn contents.

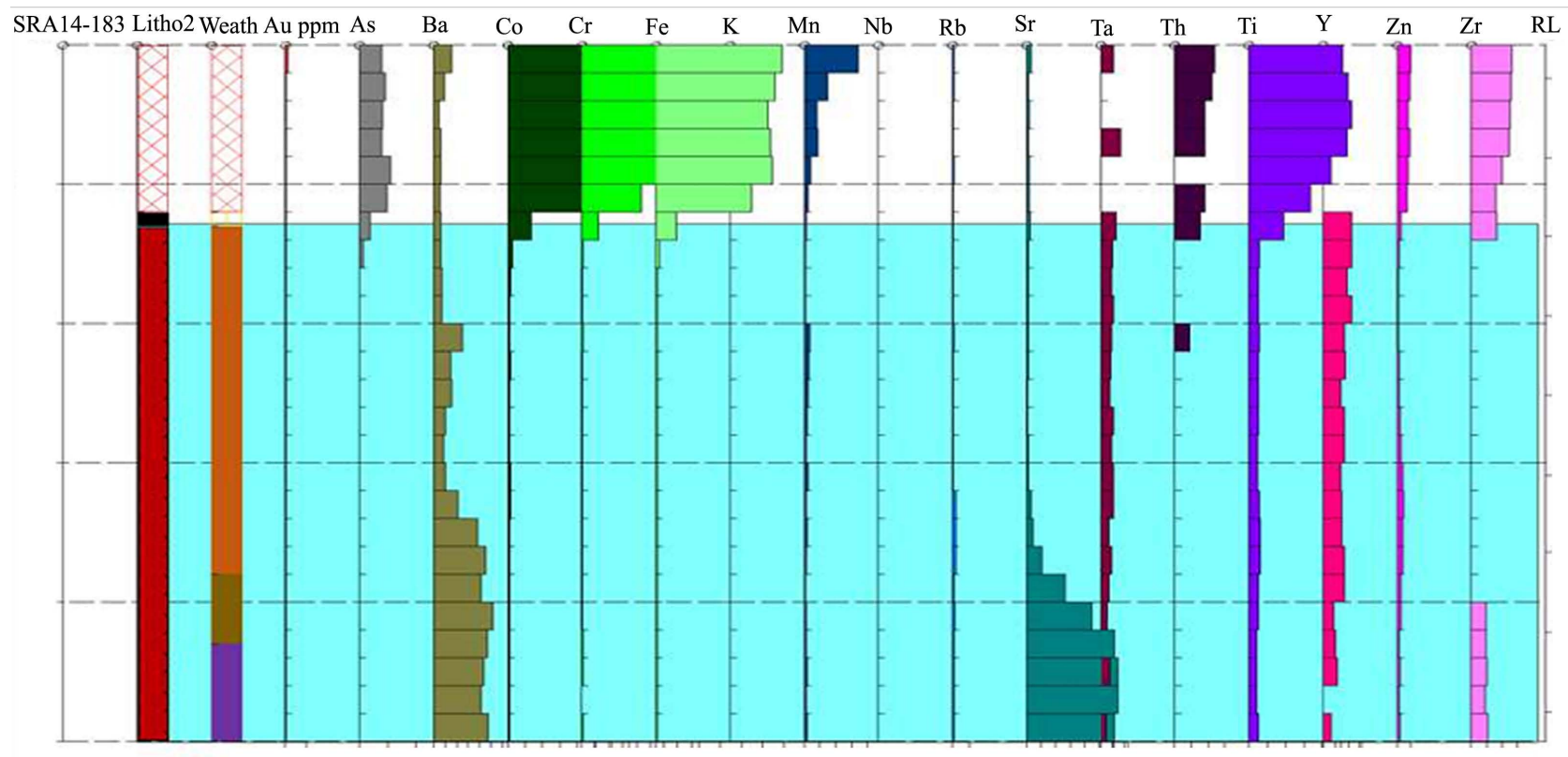

Figure 6. Strip log showing the variation of chemical elements in granite. 


\subsection{Coarse Sediments}

The coarse sediments described consist of sandstones and greywackes whose geochemical signatures are as follows:

In the greywackes, we notice mean values of $\mathrm{Ti}, \mathrm{Y}, \mathrm{Zr}$, with a decrease in $\mathrm{Cr}$, $\mathrm{Co}, \mathrm{Fe}$, whose values remain substantially constant and the absence of $\mathrm{Mn}$. As for sandstones we observe peaks in $\mathrm{Sr}, \mathrm{Ba}$, $\mathrm{Th}$, and $\mathrm{Zr}$, against a decrease in $\mathrm{Ti}$, Y. Elements such as $\mathrm{Cr}, \mathrm{Co}, \mathrm{Fe}, \mathrm{Mn}$ are almost zero. $\mathrm{Zn}$ has similar behavior in greywackes than in sandstones (Figure 7).

\subsection{The Fine Sediments}

In fine sediments, the geochemical characteristics marking the shales are as follows: there is an increase in $\mathrm{Th}$ and $\mathrm{Zr}$ and a depletion of the elements $\mathrm{Ti}, \mathrm{Y}, \mathrm{Sr}$, and also low values of $\mathrm{Cr}, \mathrm{Co}, \mathrm{Fe}$ are visible on the log (Figure 8).

\subsection{The Markers of Gold Mineralization Following the Result XRF Analysis}

The individualized observation of the strips logs reveals that:

As a result of the observations, we note that only Arsenic is the element most correlated with gold with a low degree $(r=0.16)$. This shows that the chemical element Arsenic does not always accompany gold. The realized logs show that some drillings have significant levels of Arsenic; there is no associated gold mineralization (Figure 9).

This discontinuous relationship between Arsenic and Gold allows us to hypothesize which, it would have two or more generations of Arsenic some of which

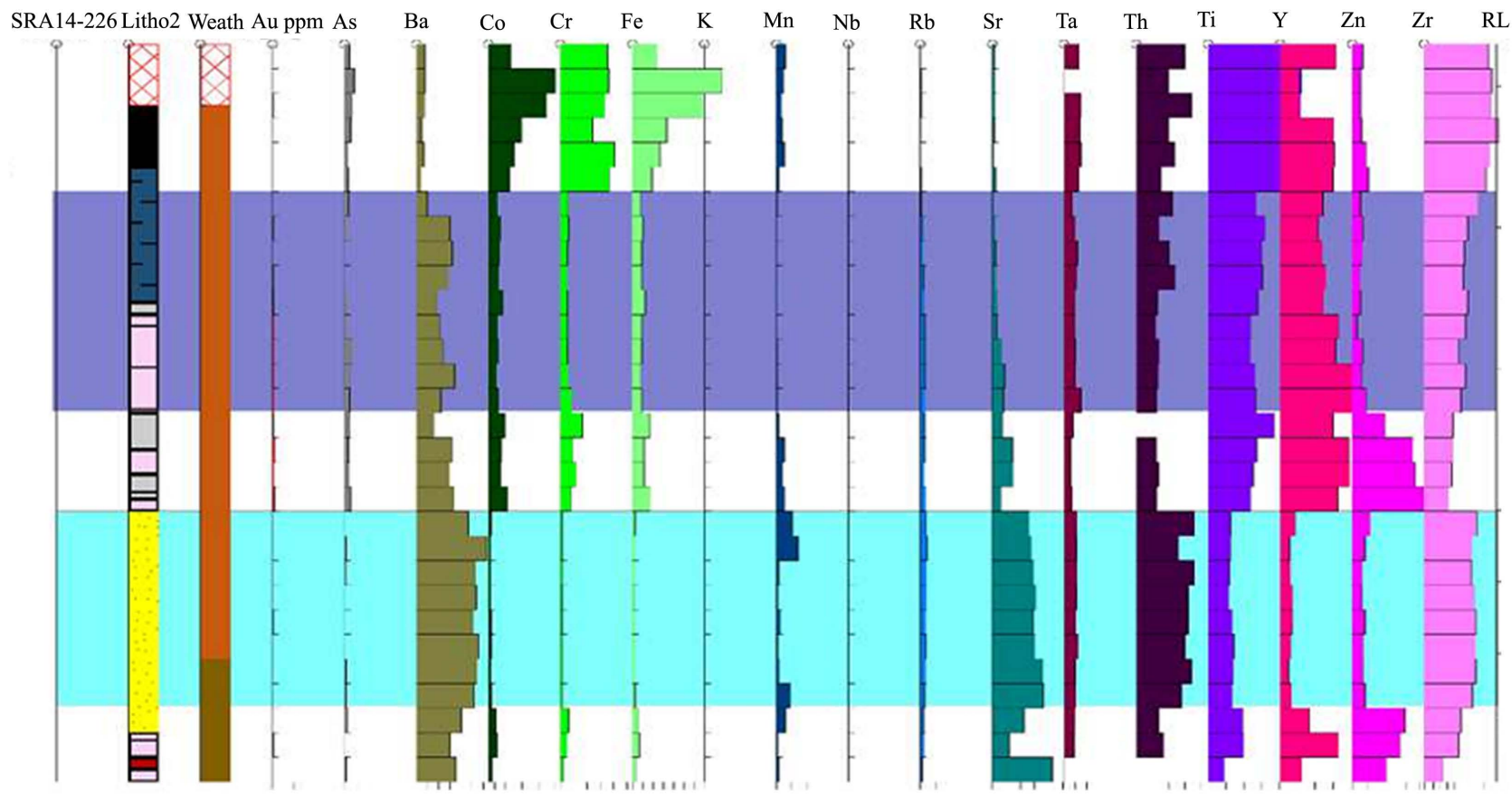

Figure 7. Discrimination of the different lithologies according to the chemical elements analyzed at XRF. 


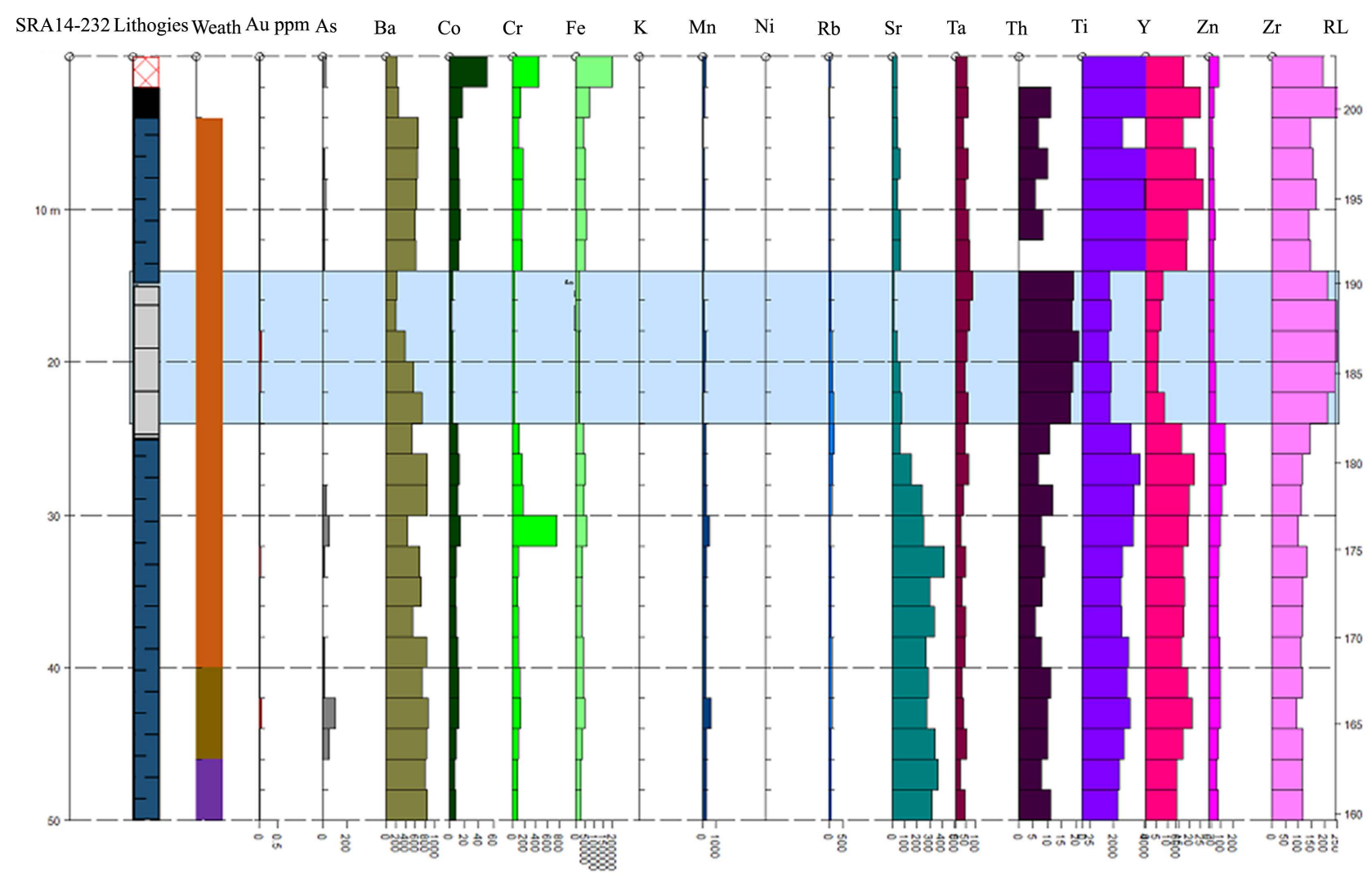

Figure 8. Strip log showing a fine sediment (Shale) between the Greywackes.

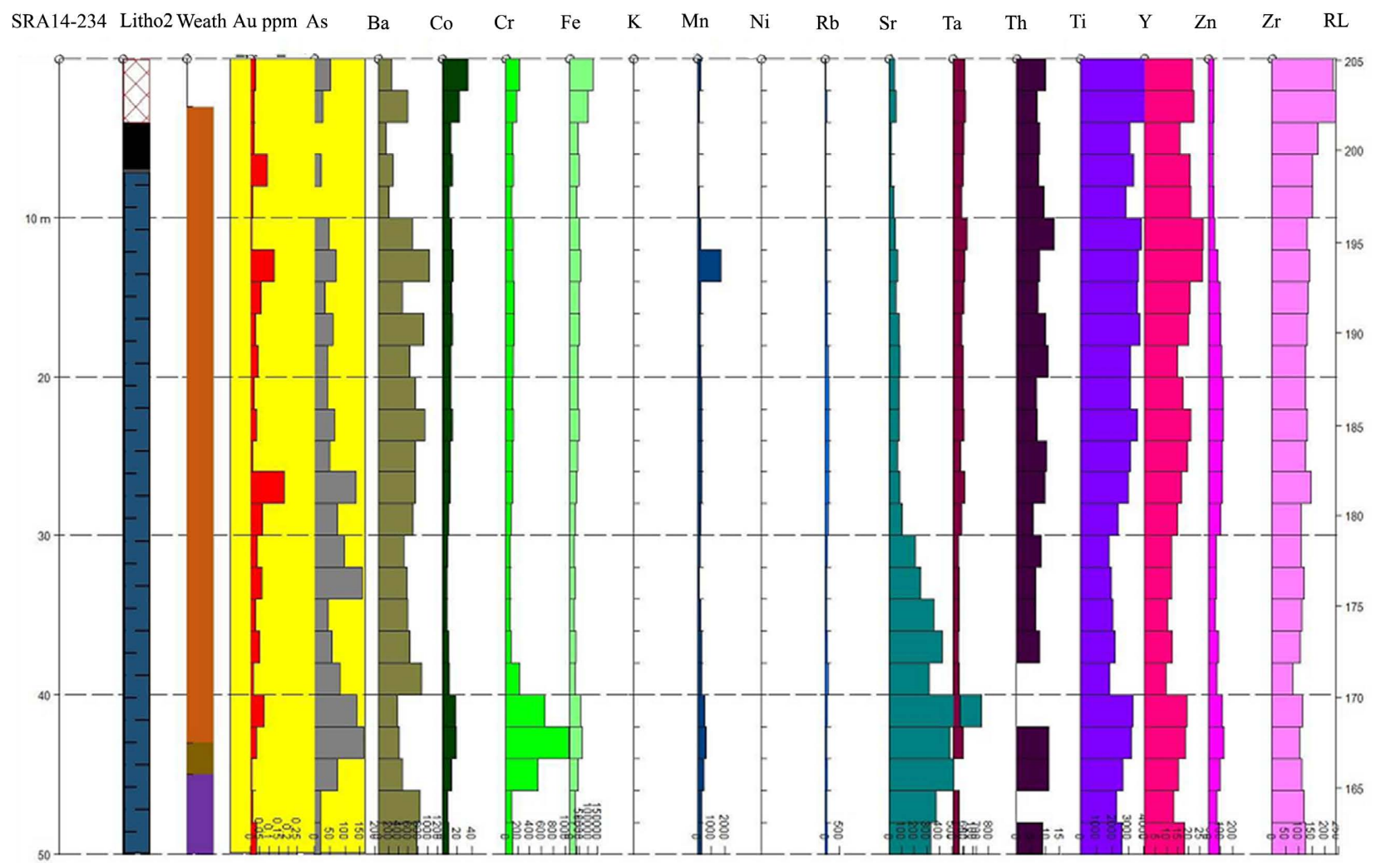

Figure 9. Strip log showing Arsenic in association with Gold (Yellow zone). 
would be related to the gold mineralization. One speciation on a large population of Arsenic could support this hypothesis.

\section{Conclusions}

In this paper, it may be noted that gold is marked in places, and at depths, a medium to strong correlation with the magnetic susceptibility data. The mineralized intervals usually consist of quartz veins, which allows advancing the hypothesis according to which the latter has a structural control on the mineralization.

In the sandstone, there is a para-genetic link between gold and arsenic, more or less strong.

Families of veins sometimes not containing gold are characterized by a high to medium magnetic susceptibility. Gold and arsenic would not be the only element at the base of magnetic susceptibility. Gold mineralization is believed to be related to quartz veins. Also, gold would be in paragenesis with a generation of Arsenic hosted in coarse sediments.

\section{Acknowledgements}

The Minister of Mines of Mali has financially supported this study research under (SYSMIN PROJECT 2002), which we would like to thank sincerely.

We send special thanks to my supervisor in state key laboratory of geological processes and mineral resources, China University of Geosciences, Wuhan and all colleagues from the University of Segou for their advice.

\section{Conflicts of Interest}

The authors declare no conflicts of interest regarding the publication of this paper.

\section{References}

[1] Mainguy, C. (2011) Natural Resources and Development: The Gold Sector in Mali. Resources Policy, 36, 123-131. https://doi.org/10.1016/j.resourpol.2010.10.001

[2] Teschner, B.A. (2014) “Orpaillage Pays for Everything": How Artisanal Mining Supported Rural Institutions Following Mali's coup d'etat. Futures, 62, 140-150. https://doi.org/10.1016/j.futures.2014.04.016

[3] Feybesse (2006) Geological Synthesis of the Malian Birimian Edition Sysmin.

[4] Hilson, G. (2012) Family Hardship and Cultural Values: Child Labor in Malian Small-Scale Gold Mining Communities. World Development, 40, 1663-1674. https://doi.org/10.1016/j.worlddev.2012.03.017

[5] Ballo, I., Hein, K.A.A., Guindo, B., Sanogo, L., Ouologuem, Y., Daou, G. and Traore, A. (2016) The Syama and Tabakoroni Goldfiefd, Mali. Ore Geology Reviews, 78, 578-585. https://doi.org/10.1016/j.oregeorev.2015.10.019

[6] Masurel, Q., Thébaud, N., Mille, J., Ulrich, S., Hein, K.A.A., Hanssen, E., Kaisin, J. and Tessougue, S. (2016) The Yatela Gold Deposit in Mali, West Africa the Final Product of Long-Lived History of Hydrothermal Alteration and Weathering. Journal of African Earth Sciences, 113, 73-87. 
https://doi.org/10.1016/j.jafrearsci.2015.10.006

[7] Hammond, N.Q., Robb, L., Foya, S. and Ishiyama, D. (2011) Mineralogical, Fluid Inclusion and Stable Isotope Characteristics of Birimian Orogenic Gold Mineralization at the Morila Mine, Mali, West Africa. Ore Geology Reviews, 39, 218-229. https://doi.org/10.1016/j.oregeorev.2011.03.002

[8] Rocci, G. (1965) Essai d'interprétation des mesures géochronologiques de la structure de l'Ouest africain. Science de la Terre, 10, 461-479.

[9] Traoré, Y.D., Siebenaller, L., Salvi, S., Béziat, D. and Bouaré, M.L. (2016) Progressive Gold Mineralization along the Syama Corridor, Southern Mali (West Africa). Ore Geology Reviews, 78, 586-598.

https://doi.org/10.1016/j.oregeorev.2015.11.003

[10] Beziat, D., Dubois, M., Debat, P., Nikiema, S., Salvi, S. and Tollon, F. (2008) Gold Metallogeny in the Birimian Craton of Burkina Faso (West Africa). Journal of African Earth Sciences, 50, 215-233. https://doi.org/10.1016/j.jafrearsci.2007.09.017

[11] Bassot, J.P., Meloux, J. and Traore, H. (1981) Géologie du Mali.

[12] Kríbek, B., et al. (2015) The Origin and Hydrothermal Mobilization of Carbonaceous Matter Associated with Paleoproterozoic Orogenic-Type Gold Deposits of West Africa. Precambrian Research, 270, 300-317. https://doi.org/10.1016/j.precamres.2015.09.017

[13] Rehren, T. and Nixon, S. (2014) Refining Gold with Glass-An Early Islamic Technology at Tadmekka, Mali. Journal of Archaeological Science, 49, 33-41. https://doi.org/10.1016/j.jas.2014.04.013

[14] Salvi, S., Sangare, A., Driouch, Y., Siwbenaller, L., Beziat, D., Debat, P. and Femenias, O. (2016) The Kalana Vein-Hosted Gold Deposit, Southern Mali. Ore Geology Reviews, 78, 599-605. https://doi.org/10.1016/j.oregeorev.2015.10.011

[15] Markwitz, V., Hein, A.A.K., Jessell, M.W. and Miller, J. (2016) Metallogenic Portfolio of the West Africa Craton. Ore Geology Reviews, 78, 558-563. https://doi.org/10.1016/j.oregeorev.2015.10.024

[16] Koné, A.Y., Nasr, I.H., Traoré, B., Amiri, A., Inoubli, M.H., Sangaré, S. and Qaysi, S. (2021) Geophysical Contributions to Gold Exploration in Western Mali According to Airborne Electromagnetic Data Interpretations. Minerals, 11, Article ID: 126.

[17] Lambert-Smith, J.S., Lawrence, D.M., Vargas, C.A., Boyce, A.J., Treloar, P.J. and Herbert, S. (2016) The Gounkoto Au Deposit, West Africa: Constraints on Ore Genesis and Volatile Sources from Petrological, Fluid Inclusion and Stable Isotope Data. Ore Geology Reviews, 78, 606-622. https://doi.org/10.1016/j.oregeorev.2015.10.025

[18] Lawrence, D.M., Treloar, P.J., Rankin, A.H., Harbidge, P. and Holliday, J. (2013) The Geology and Mineralogy of the Loulo Mining District, West Africa: Evidence for Two Distinct Styles of Orogenic Gold Mineralistion. Economic Geology, 108, 199-227. http://dx.doi.org/10.2113/econgeo.108.2.199

[19] Diallo, M., Baratoux, L., Dufréchou, G., Jessell, M.W., Vanderhaeghe, O., Ly, S. and Baratoux, D. (2020) Structures of Paleoproterozoic Kédougou-Kéniéba Inlier (Senegal-Mali) Deduced from Gravity and Aeromagnetic Data. Journal of African Earth Sciences, 162, Article ID: 103732.

https://doi.org/10.1016/j.jafrearsci.2019.103732

[20] Koné, A.Y., Nasr, I.H., Belkheria, W., Inoubli, M.H., Amiri, A. and Ly, S. (2019) Structural Setting of Western Mali Insights from Magnetic Data Analysis. In: Sundararajan, N., Eshagh, M., Saibi, H., Meghraoui, M. and Giroux, B., Eds., On Significant Applications of Geophysical Methods. CAJG 2018. Advances in Science, 
Technology \& Innovation (IEREK Interdisciplinary Series for Sustainable Development), Springer, Cham, 25-27.

https://doi.org/10.1007/978-3-030-01656-2_5

[21] Koné, A.Y., Nasr, I.H., Belkhiria, W., Inoubli, M.H., Sangaré, S. and Traoré, B. (2019) Structural Controls of Gold Mineralization in Western Mali: Insights from Electromagnetic Data Analysis. Proceedings of the International Workshop on Gravity, Electrical \& Magnetic Methods and Their Applications, Xi'an, 19-22 May 2019, 383-385. https://doi.org/10.1190/GEM2019-097.1

[22] Hein, K.A.A., Matsheka, I.R., Bruguier, O., Masurel, Q., Bosch D., Caby, R. and Monié, P. (2015) The Yatela Gold Deposit: 2 Billion Years in the Making. Journal of African Earth Sciences, 112, 548-569.

https://doi.org/10.1016/j.jafrearsci.2015.07.017 